AGNIESZKA BRELIK

PIOTR KUŁYK

\title{
The evaluation \\ of the attractiveness \\ of the tourist commune \\ as conditioning \\ of the development \\ of agricultural tourism \\ farms
}

Ph.D. Agnieszka Brelik West Pomeranian University of

Technology Szczecin

Ph.D. Piotr Kułyk University of Zielona Góra

Faculty of Economics and Management

\section{Introduction}

Rural communities in Poland exhibit significant spatial variations in the degree of socio - economic development, structure of the settlement, and the state of social and technical infrastructure. This diversity results from the impact of factors such as: location, rank and the nature of agriculture in the regions' development, the demographic situation, the situation on the labour market, rural resources, the activity of local governments and local communities, local skills and traditions. Consequently, the methods of development are varied. On the one hand, the development of rural tourism in rural areas can be an alternative to traditional courses directly related to agriculture and the associated services. On the other hand, it can be an important supplement based on the resources of rural areas and agriculture. Therefore, it is also possible, at least in part, to introduce charges for the provision of public goods. Indeed agritourism farms are based on a number of public goods provided by agriculture, such as fresh air, open spaces 
and environmental or cultural values. However, the concept based on the development of rural tourism faces many obstacles. Considering the changes in rural development and transformation taking place in agriculture we should pay attention to the importance of tourism. Rural areas and agriculture can be activated by inspiring actions taken by the farmers in rural tourism and expansion, improvement of tourist use of natural and cultural assets in rural areas. The development of tourism in rural areas is possible. More than half of rural communities meet the criteria for recreational space and has favourable conditions for development of tourism. However, it is noted that there are significant barriers concerning human capital. They influence the decision to be taken in shaping changes in rural areas and do not allow full use of the existing possibilities. The purpose of this study is to determine the relationship between the assessment of the attractiveness of rural communities and the agro-economic, social and environmental factors characterizing farms. We were taken into account: age, sex, education, incomes, evaluation authorities' attitude to society and opinion on the cleanliness of the environment in the municipality of the farm owner. This will allow a better understanding of the decisions made by the farm owners.

\section{Material and research methods}

The research on the evaluation of agritourism attraction in the community was carried out in the Western Pomerania communities. The questionnaire method was used to collect data. Researches were realized in 2012 by qualified interviewers cooperating with Centers of the Agricultural Consultancy, i.e. inspectors having the many years' experience in the realization of this type of research. This permitted the obtainment of the statistical material about the relatively high reliability and the formal correctness. A research tool was the questionnaire of the interview entitled "The Agricultural tourism in the structure of public goods". The first part the questionnaire characterized farms and their structure and socio-economic features. The second part of the questionnaire raised an issue related to the evaluation, which changes in operate of the agricultural tourism activity should follow for the achievement of the maximum multi-functionality of the agriculture with the regard of the delivery through it public goods. The formal correctness and essential of the questionnaire was verified during pilotage research carried out in the year 2011 (40 agricultural tourism farms) underway the consultation with workers ODER's. From among all agricultural tourism farms to the evaluation and the designation

$x=$

AGNIESZKKA BRELIK

PIOTR KUŁYK 
of the size sample one took into account only these which were greater from 4 $\mathrm{ESU}^{1}$. Essential is because the element of the economic activity resulting from the agricultural production. The number of such farms in the province West Pomeranian carries out amounts close 190. Investigations were carried out on the full population, however due to the refusal of the answer and also errors into resultant during the pursuance of questionnaires to the evaluation one accepted 162 agricultural tourism farms. The representative attempt in case of the descriptive problem in quantitative research would amount in this case 156 farms at the confidence level 0,95 and the maximum acceptable error 0,03. Were fulfilled therefore terminal requirements of the adopted number of units. One can accept, that it warranted to preliminary verifying of placed exploratory hypotheses. In order to identify factors differentiating the attractiveness of the researched communities by the agritourism farms owners and the relationship between them $\chi^{2}$ test of independence, which allows to determine the statistical significance of the relationship between both measurable and non-measurable variables, was used. The test involves comparing the number of responses received in a number of researches that can be expected under the assumption that there are no relationships between the analysed variables. The values of $\chi^{2}$ and degrees of freedom (df) are working and are generally not assessed. The interpretation covers primarily the level of probability (p), on the basis of which the existence or lack of dependence are predicated. The article adopted a critical significance level $\mathrm{p}<0.10$.

The literature provides the most common distinction between internal and external factors determining the development of agritourism holiday. While emphasizing sustainable development of rural areas and sustainable rural development, rural tourism development conditions primarily include: natural and cultural community; attractive landscape, the specificity of the region, communities, villages, tourist attractions, adapting rural homes and surroundings to the tourists. The hereby study involves the key factors of the demographic characteristics of the agritourism farms owners, while analyzing their decisions to undertake such activities and for assessing the attractiveness of the location.

1 ESU (European Size Unit) - the universal unit by means of which one determines the size of farms estimating their economic force across the evaluation of the profitability. The designation of the economic size of farms (about the different pattern of production) takes place on the basis regional coefficients of The Standard Gross Margin for plant products and animal. 1 ESU = 1200 EUR (Hyytia, Kola 2006).

The evaluation of the attractiveness

of the tourist commune as conditioning of the development of agricultural tourism 
The available data storage statistics do not specify the precise scale projects related to rural tourism and the number of people taking a rest in agritourism farms. Therefore, the questionnaire method was used to collect the raw data. The number of farms involved in agritourism and rural tourism is increasing every year in the majority of Polish regions. In many countries of the European Union, the number of farms offering agritourism services is growing rapidly, e.g. in Italy the number of such farms in the years 2007-2003 doubled (OECD 2008). In 2005, in Poland there were 18,653 individual accommodation facilities (including 6,550 lodging agritourism) offering 309,157 beds (including 7,692 rural tourism lodging). In 2009 the number of agritourism accommodation increased to 8,402 i.e. by $9.62 \%$ (calculation based on: Bieńkowska 2009, p 50). The number is not significant, which in case of support for such initiatives from the European Union funds indicates the presence of significant barriers to the formation of this type of activity. The number of beds in agritourism farms increased much faster (by 33.19\%), indicating the rapid expansion of existing farms. The largest number if facilities were found in Pomerania, Lesser Poland and Western Pomerania Regions. Some of the regions faced sharp decline in farms number in 2010 compared to 2007 (Warmia and Mazury, Pomerania, Podlaskie, Subcarpathian Regions), which may result from the reduction in tourist activity due to the global crisis. This mainly concerned the so called "Eastern Wall" and regions with high environmental valuers, which may be quite interesting and surprising. The largest increase was recorded in the South (the regions of Silesia and Lesser Poland) and in the South-West (Lubuskie, Greater Poland and Western Pomerania). According BednarekSzczepanska (Bednarek-Szczepańska 2010) the distribution of agritourism hotels in Poland is weakly associated with the distribution of the collective accommodation facilities in general. Some communities are characterized by a relatively high level of development of tourism, despite the moderate values of tradition and lack of tourism tradition. Guest rooms operate mainly in cities with well-developed tourism and function of a large number of collective accommodations. Therefore, it is worth to take a closer look to the opinion of the owners of such entities assessing the attractiveness of the community in terms of agritourism business. The evaluation is essential from the point of view of the adaptation of the financial support of agriculture to the possibility of the obtaining of determined public goods, especially, that both needs how and itself support show the considerable differentiation both on level domestic as and regional (Kułyk 2009).

$X \times$ 


\section{The relationship between demographic and economic structure of farm owners and farms and the assessment of the attractiveness of the community}

The concept of multifunctional agriculture is based on the assumption that agriculture can provide important non-production functions for the society, which is not achieved by other sectors of the economy. The multifunctionality of agriculture has its own historical background. For centuries agriculture has shaped the landscape and has been a part of the traditions of many regions. As a result, it provides a number of public goods, such as (Van Huylenbroeck, Durand 2003; Brouwer 2004, Cahill 2001): the conservation of biodiversity, the maintenance of landscape aesthetics, space, conditions for recreation, water accumulation, nutrient recycling and preserving wildlife, protecting against extreme weather events and flood. According to a research conducted by R.J. Brunstad, I. Gaasland, E. Vårdal (1999, p. 539) non-production functions are gaining importance in the developed countries and introducing fees for them are becoming more accepted by societies in those countries. In the case of agricultural multifunctionality, it means that the assessment of the contribution of farms to the socio-economic system requires common consideration of all externalities generated in the operation of farms (Randall 2002, pp. 290-292). The very concept of providing non-food agricultural goods is not new and of itself, is not controversial. However, the problem is the possibility to provide economic benefits for the implementation of non-production functions. The often posed complaint is the question of excessive social and environmental functions combining only to agriculture. Multifunctionality is not a phenomenon reserved only for agriculture, but there are specific problems as well as public goods produced in the sector. A very important feature in this context is the natural character of the resources (especially land) in agriculture. It is therefore necessary to state clearly that the lack of formation of the markets does not provide a valuation and consequently payment for the provision of public goods by agriculture (Czyżewski, Kułyk 2011).

The property rights and the ability to unambiguously assign property rights to certain assets are key features, and consequently arising public goods. This often requires regulation by the state, so as to be able to assess properly the entity's contribution to the creation of good. Then it is possible to, at least partially, implement the market fee for the provision of public goods, which allows simultaneously to increase farmers' incomes, and thus move the profitable agricultural production by reducing the over-intensification. One of the sample solutions is to promote the development of agritourism. In the European Union

The evaluation of the attractiveness

of the tourist commune as conditioning

of the development of agricultural tourism 
agritourism is supported and funded by the European Leader Program, which aims to promote endogenous, integrated and sustainable development in rural areas. Agritourism activity in this approach is combined with agricultural production by "complementary binding". In this sense, rural tourism is based on the benefits provided by the farm, and cannot exist without agricultural production. Therefore, in some countries in the detailed solutions it is reserved that agritourism activities may apply only to farms that produce agricultural production at the same time (e.g. the provisions of Italian law - (OECD 2005, pp. 34-40). Thus other benefits are implemented for the development of tourism. Furthermore, both diversification and modernization of agriculture occur, as well as a better use of the resources involved (especially the labour force). Such solutions also shape the complex relationship between agricultural production and the provision of public and private goods, provide benefits, and from their production. Adopted regulations concerning property rights in the concept of multifunctionality of agriculture at the same time takes into account several aspects: the connection between agricultural production and reducing externalities and market imperfections allocation, which in other case does not allow the market to ensure the benefits of the provision of public goods. The implementation of the concept of eco-tourism focused primarily on preserving the environment and promoting environmental awareness among tourists and local residents became an extension of this idea and indicated differentiation compounds.

Due to the competition with traditional agricultural products and high price flexibility of demand prices for agricultural products, farmers do not pay much attention to properly maintain the environment (OECD 2008). Because the regard environmental requirements without the assertion of economic advantages will lead to the deterioration of the price competitiveness. The problem lies in the proper assessment of the benefits to be gained from promoting farmers for organic production and increasing concern for the environment. It may be noted that the commitment to the development of tourism activities on farms is dependent on the perception of their owners of the benefits of such activities and, indirectly, the attractiveness of the area in terms of the possibility of such activity (Brunstad, Gaasland., Vårdal 1999). The awareness of the impossibility of the smooth functioning of tourism and tourism product development without attractive natural assets on the one hand, and awareness of the increase in requirements of tourists to the natural environment on the other hand means the attitudes of the inhabitants of communities are becoming more ecological (Rapacz, Gryszel, Jaremen 2008). 
The assessment of communities' attractiveness by the farm owners was analysed due to the demographic characteristics of the respondents. The gender of the head of the household was the first of the analyzed factors. It turned out that gender generally does not differentiate the assessment of communities' attractiveness. Most of the residents of the West Pomerania communities indicates that the community is attractive for coming tourists, $10 \%$ of respondents, including men, disagreed with this opinion, and almost 5.1\% did not answer the question. However, it should be noted that the percentage of the assessment of communities attractiveness, the head of which are women or men, are quite similar, with a slight predominance of farm women, $63.2 \%$ of whom assessed phenomenon as attractive.

Table 1. The gender of the head of the agritourism farm and tourist communities' attractiveness

\begin{tabular}{l|c|c|c|c}
\hline \multirow{2}{*}{ Gender } & \multicolumn{4}{|c}{ Assessment of attractiveness of the researched communities } \\
\cline { 2 - 5 } & very good & good & bad & total \\
\hline Men & 55,0 & 35,0 & 10,0 & 100 \\
\hline Women & 36,8 & 63,2 & 0,0 & 100 \\
\hline Total & 46,2 & 48,7 & 5,1 & 100 \\
\hline$X^{2}$ test & \multicolumn{5}{|c}{$\chi^{2}=0,981 \mathrm{df}=2 ; \mathrm{p}=0,6142$} \\
\hline
\end{tabular}

Source: own research

In contrast to gender, age is the factor that differentiates largely the assessment of the attractiveness of the community by the agritourism farms owners. The research found statistically significant differences between the age of the head of agritourism farms and the assessment of communities attractive for tourists (table 2).

Considering the evaluation of the attractiveness of the commune in respect of tourist does not appear the one-way tendency to the growth or the fall of this evaluation together with the age of respondents. One can however see significant differences among individual age groups. The highest percentage of persons evaluating high the tourist attractiveness of examined communes was highest in the group 26-35 years and 46-55. Most critically the attractiveness of the commune evaluated respondents from the age span 36-45. This is

The evaluation of the attractiveness

of the tourist commune as conditioning of the development of agricultural tourism 
age group being conspicuous highest on examined areas an activity ratio of professional (87,9\% GUS 2013). This is therefore the phenomenon alarming and the indicative of occurrence of express restrictions for the development of agricultural tourism farms in virtue of the attractiveness of the region. Relatively the low of the evaluation of the attractiveness appeared also in the band above 65 the age year.

Table 2. The age of the head of the agritourism farms and the assessment of attractiveness of the researched communities

\begin{tabular}{|c|c|c|c|c|}
\hline \multirow{2}{*}{ Age } & \multicolumn{4}{|c|}{ Assessment of the attractiveness of the researched communities } \\
\hline & very good & good & bad & total \\
\hline $18-25$ & 53,8 & 46,2 & 0,0 & 100 \\
\hline $26-35$ & 70,0 & 30,0 & 0,0 & 100 \\
\hline $36-45$ & 9,1 & 72,7 & 18,2 & 100 \\
\hline $46-55$ & 60,0 & 40,0 & 0,0 & 100 \\
\hline Above 65 & 46,2 & 48,7 & 5,1 & 100 \\
\hline Total & 53,8 & 46,2 & 0,0 & 100 \\
\hline$X^{2}$ test $=12,09$ & \multicolumn{4}{|c|}{$X^{2}=12,09 \mathrm{df}=6 ; p=0,0601$} \\
\hline
\end{tabular}

Source: own research

Table 3. Strength of the relationship between the assessment of the community attractiveness for residents and gender, age, education and income of the researched respondents

\begin{tabular}{|c|c|c|c|c|c|c|c|c|c|c|c|c|c|c|c|c|}
\hline \multirow{3}{*}{$\begin{array}{l}\text { Researched } \\
\text { aspect }\end{array}$} & \multicolumn{16}{|c|}{ Analysed variable } \\
\hline & \multicolumn{4}{|c|}{ gender } & \multicolumn{4}{|c|}{ age } & \multicolumn{4}{|c|}{ education } & \multicolumn{4}{|c|}{ Income } \\
\hline & $x^{2}$ & df & $\begin{array}{l}\text { critical } \\
\text { value }\end{array}$ & $\mathrm{p}$ & $X^{2}$ & $\mathrm{df}$ & $\begin{array}{c}\text { critical } \\
\text { value }\end{array}$ & $\mathrm{P}$ & $x^{2}$ & df & $\begin{array}{l}\text { critical } \\
\text { value }\end{array}$ & $\mathrm{p}$ & $x^{2}$ & df & $\begin{array}{l}\text { critical } \\
\text { value }\end{array}$ & $\mathrm{P}$ \\
\hline $\begin{array}{l}\text { Assessment } \\
\text { of the } \\
\text { community } \\
\text { attractive- } \\
\text { ness for } \\
\text { residents }\end{array}$ & & & & & & & & & & & & & & & & \\
\hline
\end{tabular}




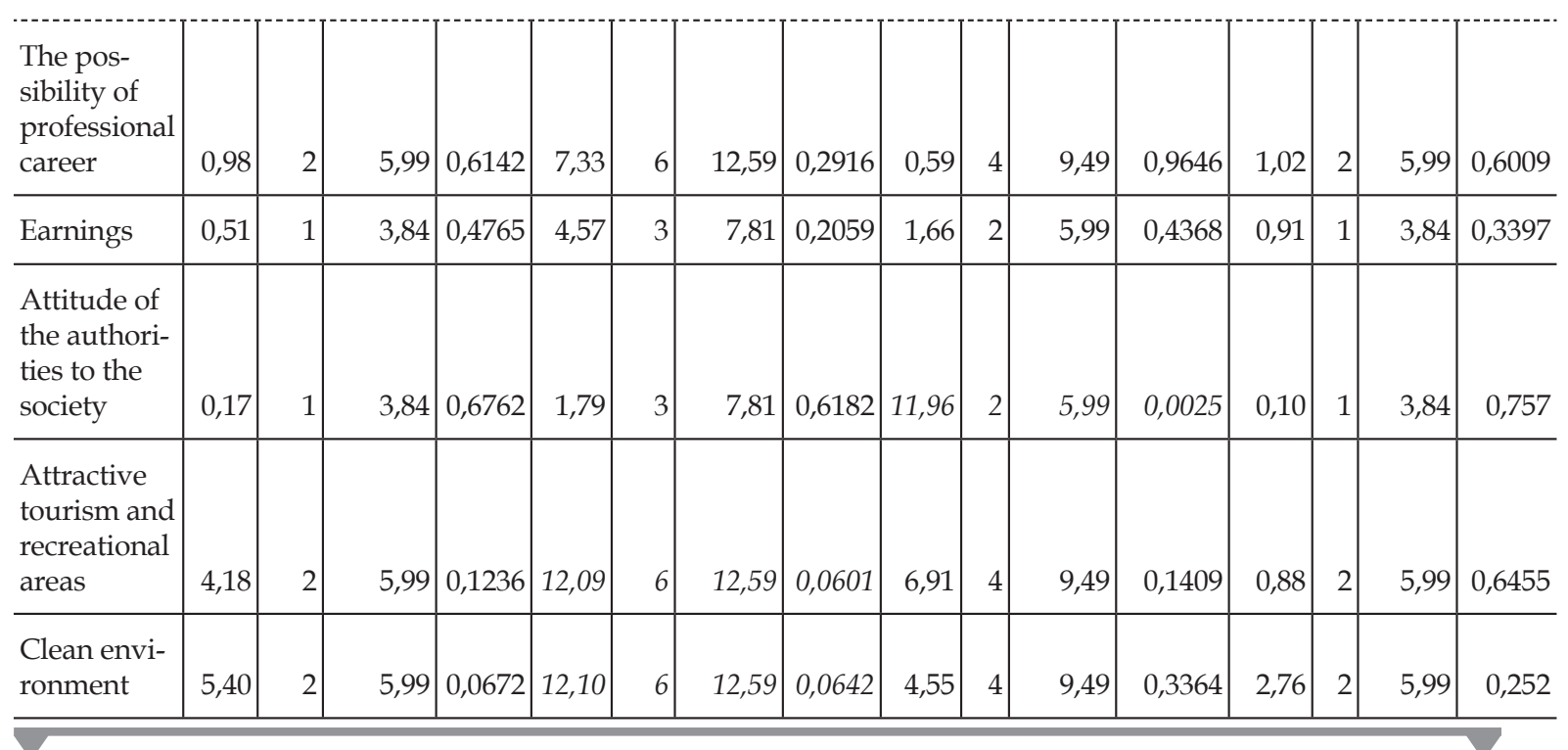

Source: own research

Table 1 presents the results of $x^{2}$ test of independence in the assessment of different aspects, depending on gender, age, education and income of the respondents. It shows the exact value of the test, the number of degrees of freedom (df), the critical value for this test, and so called p-value, which limit the level of significance. Italics in the table indicates the cases for which the relationship between the measured features is considered as statistically significant (in accordance with the adopted foundation $p<0,10$ ). It can be noted that there are only three of those cases: very important dependency is between the relationship of education and the assessment of the authorities' attitude to the society $(p=0.025$ - dependence) and between age and the assessment of attractive tourist and recreational areas $(p=0.0601)$ and the clean environment $(p=0.0642)$. These three parameters differentiate answers of respondents and influence the evaluation of the attractiveness of the commune. What interesting both possibilities of the formation of the career nor the height of earnings are not determined indicated features. Respondents for the particularly essential aspect of the attractiveness of communes of the province West Pomeranian acknowledged first of all the purity of the environment. Whereat this evaluation was determined an age structure of respondents. Also an important discriminator was the relation of authorities to the society. However in this case the evaluation of this aspect was subordinated from the structure of the education of respondents.

The evaluation of the attractiveness of the tourist commune as conditioning of the development of agricultural tourism 
The characteristics of the above dependencies is illustrated in detail in table 4 , which presents the so called odds ration comparing the likelihood of a twostage assessment of the aspect, e.g. what are the chances of a given aspect of the assessment as "good" and which as "bad".

Table 4. Selected odds ratios describing the researched variables

\begin{tabular}{|c|c|c|c|c|}
\hline Researched aspect & Analysed variable & Type of odds ratio & $\begin{array}{l}\text { Variable } \\
\text { variant }\end{array}$ & $\begin{array}{c}\text { The value } \\
\text { of odds } \\
\text { ratio }\end{array}$ \\
\hline \multirow{3}{*}{$\begin{array}{l}\text { Attitude of the authorities } \\
\text { to the society }\end{array}$} & \multirow{3}{*}{ Education } & \multirow{3}{*}{ "good" / „bad" } & vocational & 1,25 \\
\hline & & & secondary & - \\
\hline & & & higher & 4 \\
\hline \multirow{4}{*}{$\begin{array}{l}\text { Attractive tourism and } \\
\text { recreational areas }\end{array}$} & \multirow{4}{*}{ Age } & \multirow{4}{*}{$\begin{array}{l}\text { "very good" / } \\
\text { "good" }\end{array}$} & $18-35$ & 1,5 \\
\hline & & & $36-45$ & 1,167 \\
\hline & & & $46-55$ & 0,125 \\
\hline & & & $56-65$ & 2,333 \\
\hline \multirow{4}{*}{ Clean environment } & \multirow{4}{*}{ Age } & \multirow{4}{*}{$\begin{array}{l}\text { very good / } \\
\text { "good" }\end{array}$} & $18-35$ & 1,5 \\
\hline & & & $36-45$ & 1,600 \\
\hline & & & $46-55$ & 10 \\
\hline & & & $56-65$ & 0,600 \\
\hline
\end{tabular}

Source: own research

Based on table 4, it can be concluded that the probability that people with higher education will assess the authorities attitude to society as "good" is 4 times higher than the chance of a negative assessment while assessment of the attractiveness of the communities of the West Pomerania. However, the chances that people aged 46-55 years indicate attractive tourism and recreational areas as "very good" are $87.5 \%$ lower than the probability that respondents will assess these values as "good". Considering the assessment of the community attractiveness for the residents in terms of clean environment can be concluded that the chances that respondents aged 46-55 years assess 
the phenomenon as "very good" is 10 times higher than the chance to assess as "good".

\section{Conclusions}

The factors affecting the tourist experience from staying in the country are largely beyond the scope of the impact of the rural accommodation, ranging from the attractiveness of tourist attractions, the services of other companies, to the generally understood the quality of life in a given place, including the availability and quality of social and technical infrastructure, safety, friendliness of local residents to visitors, the number and behaviour of other tourists (Kachniewska 2009). A significant part in shaping the quality of tourist offer of the town have nature goods (the original) and public goods that affect not only the shape of the tourist offer, but also the quality of life of local residents. Economic, social and ecological balance is considered to be key factors affecting the competitiveness of tourist destinations in the long term. Finding the right balance between the free development of tourist reception areas and the protection of their resources is a very difficult task. It is related to the implementation of the concept of multifunctional agriculture providing both private and public goods.

The analysis of the questionnaire results included in the hereby study showed that in the Western Pomerania the owners of agritourism farms assess the researched communities as good in terms of their attractiveness and clean environment. This shapes the possibility of the development of the agricultural tourism and the differentiation of the activity on rural areas, but also deliveries of public goods. The special meaning is credited the part of the clean environment. The research has shown a strong correlation between owners' age and clean environment assessed by them as well as education and attitude of the authorities to the society. The environmental awareness of communities residents is also increasing, which directly relates to the quality of life of the society. It should be noted that this area, in which a relatively fast (compared to other regions of the country) increase was observed, considers both farm tourism, and accommodation in these farms. The significant association between the perception of the communities attractiveness by the farm owners and the decisions about their development and conversion of farmhouses is observed. This shapes simultaneously important premises to the financing of public goods through the mediation of the state and also the market (increasing advantages from the care for the natural environment), but also the need for paying attention on the ancient differentiation of owners of

The evaluation of the attractiveness

of the tourist commune as conditioning

of the development of agricultural tourism 
agricultural tourism farms and the part of local authorities in creating of the development of communes.

\begin{abstract}
The evaluation of the attractiveness of the tourist commune as conditioning of the development of agricultural tourism farms The paper presents the relationship between the variables of the attractiveness of communities of the Wets Pomeranian and economic, social and ecological variables as feature of agritourism farms owners. The $x^{2}$ test of independence was used in order to identify factors differentiating the attractiveness of the surveyed communities by the farmhouses and the relationship between independence. The attention was drawn to the concept of multifunctionality of agriculture and the importance of the tourism activities.
\end{abstract}

Key words: agriculture, agritourism, multifunctional agriculture.

\title{
Streszczenie
}

Ocena atrakcyjności turystycznej gminy jako uwarunkowanie rozwoju gospodarstw agroturystycznych

W pracy przedstawiono zależności między zmienną określającą ocenę atrakcyjności gmin województwa zachodniopomorskiego a zmiennymi ekonomicznymi, społecznymi i ekologicznymi charakteryzującymi właścicieli gospodarstw agroturystycznych. W celu zidentyfikowania czynników różnicujących poziom atrakcyjnościbadanych gmin przez gospodarstwaagroturystyczne oraz związków zachodzących pomiędzy nimi wykorzystano test niezależności $\chi 2$.Zwrócono uwagę na koncepcję wielofunkcyjności rolnictwa i znaczenie w niej działalności agroturystycznej.

\section{Słowa}

kluczowe: rolnictwo, agroturystyka, wielofunkcyjność rolnictwa.

\section{References}

1. Bednarek-Szczepańska M. (2010), Kwatery prywatne w przestrzeni turystycznej Polski. Prezentacja na konferencji: 20 lat przemian społecznogospodarczych krajów Europy Środkowej i Wschodniej- próba bilansu. Polańczyk, 14-17 czerwca. 
2. Brelik A., Matuszczak A. (2013), Issues of Public goods in Multifunctional Development of Rural Areas, "Economic Science for Rural Development Conference Proceedings", Issue 31, s. 28-32.

3. Brouwer F. (2004), Sustaining Agriculture and the Rural Environment: Governance, Policy and Multifunctionality. EdwardElgar Publishing, Cheltenham.

4. Brunstad R.J., Gaasland I., Vårdal E. (1999), Agricultural production and the optimal level of landscape preservation. "Land Economics", Vol. 75.

5. Cahill C. (2001), The multifunctionality of agriculture: what does mean? "EuroChoices", vol.1, no. 1.

6. Czyżewski A., Kułyk P. (2011), Public goods in multifunctional agricultural development. The attempt on problem conceptualisaton w: D. Kopycińska (ed.), Selected problems of market economy in the crisis era / .- Szczecin: Wydaw. Naukowe Uniwersytetu Szczecińskiego, Szczecin.

7. GUS (2013), Kwartalna informacji o aktywności ekonomicznej ludności, GUS, Warszawa.

8. Hyytia N., Kola J., (2006), Finnish citizens' attitudes towards multifunctional agriculture, "International Food and Agribusiness Management Review", No. 9 (3), s. 1-22.

9. Kachniewska (2009), Funkcja turystyczna jako determinanta jakości życia $n a$ wsi. FOLIA POMERANAE UNIVERSITATIS TECHNOLOGIAE STETINENSIS, “Oeconomica”, No. 288 (64).

10. Kułyk P. (2009), Retransfer of incomes in selected developing and developed countries, "Economic science for rural development: proceedings of the international scientific conference", Jeglava.

11. Kurtyka I. (2012), Baza noclegowa w Polsce w latach 1997-2010 ze szczególnym uwzględnieniem bazy noclegowej indywidualnego zakwaterowania. Roczniki Naukowe Stowarzyszenia Ekonomistów Rolnictwa i Agrobiznesu, Tom XIV Zeszyt 1, Warszawa-Poznań-Białystok.

12. Niezgoda A. (2006), Obszar recepcji turystycznej w warunkach rozwoju zrównoważonego. Akademia Ekonomiczna w Poznaniu. Prace habilitacyjne 24. Wyd. Akademii Ekonomicznej w Poznaniu, Poznań.

13. OECD (2005), Multifunctionality in Agriculture. What role for private initiatives?, Paris.

14. OECD (2008), Multifunctionality in Agriculture: Evaluating the Degree of Jointness, Policy Implications, Paris.

15. Randall A. (2002), Valuing the outputs of multifunctional agriculture, "European Review of Agricultural Economics", No. 29(3).

The evaluation of the attractiveness

of the tourist commune as conditioning

of the development of agricultural tourism

farms 
16. Rapacz A., Gryszel P., Jaremen D. (2008), Udział mieszkańców realizacji idei zrównoważonego rozwoju w gminach turystycznych. Turystyka jako czynnik wzrostu konkurencyjności regionów w dobie globalizacji. Wyd. Akademii Ekonomicznej, Poznań.

17. Van Huylenbroeck G., Durand G. (2003), Multifunctional agriculture, a new paradigm for European agriculture and rural development, Ashgate, London. 